\title{
HOW CAN WE ENFORCE OUR EXCLUSION LAWS?
}

\section{By Marcus Braun,}

Immigrant Inspector, Department of Commerce and Labor, Washington, D. C.

From the Atlantic to the Pacific Ocean we have, I believe; on the Canadian border, a stretch of about 4,000 miles; the southern boundary from Brownsville to Tia Juana is, I believe, about 2,500 miles long, making a total of about 6,500 miles. On these two borders the United States Government maintains an immigrant inspection service consisting of perhaps all told 300 officers and other employees. These officers and employees, generally speaking, are a fine body of men, well trained and usually very much devoted to the service. At their disposal are the various laws and regulations which read very smoothly and which in theory are excellent. When it comes to practical enforcement, it is a different thing.

The best guarded border line that I know of in any country is in Russia, where the government places at every wierst (about ninetenths of an English mile) an armed guard, day and night in three shifts for every twenty-four hours. These Russian frontier guards have the most far-reaching power and authority, they can arrest anybody who crosses the frontier, whether in possession of papers or not; they have a right to shoot, to kill, and yet, with this immense apparatus at their disposal, there are thousands and thousands of people smuggled out of Russia and smuggled into Russia. How much easier must be the smuggling of aliens across our northern and southern boundary lines. I am not in possession of the latest statistical data as to how many Japanese and Chinese officially entered within the last year into the United States, but I am sure that no matter how large or small the number is, many more entered the country surreptitiously.

The smuggling of Chinamen and Japanese is a regular profession on these two border lines; it is not a very risky undertaking, and it pays very well, from $\$ 25.00$ to $\$ 200.00$ per head. When I say that it is not a risky undertaking, I mean to indicate thereby that the smuggler of Chinamen and Japanese on the two borders very seldom crosses the border line; he merely brings his wards to the border and he tells them to run across. True, there may be on 
the American side someone or several persons who will show the way to these smuggled Chinamen and Japanese further, but if those men are caught, we can hardly get them convicted of having smuggled these Orientals into the country, because they merely picked them up on American soil and showed them the way.

Another bad feature is that the highly technical rules governing the admission of evidence before our tribunals make it many times almost impossible to secure convictions, aye, far worse, many Chinamen who were smuggled into the country during the night at some convenient place, have had and have the audacity to present themselves the next morning at the office of our Chinese inspector in charge, with an affidavit, made by someone in some interior city of the United States, in which affidavit it usually is stated that so and so is a merchant or a laundryman, residing for the last ten or fifteen years, to the knowledge of the affiant, in that particular city, and that so and so went on a pleasure trip or on a business trip to some particular place on or near the border line. Armed with such an affidavit, the Chinaman asks our Chinese inspector in charge to endorse his paper, in order that he may not be held up at the railroad station when trying to board a train to some interior point.

Experience has shown that when the inspector in charge refuses to make an endorsement on such a manufactured document, and places the Chinaman under arrest, he is subsequently admitted by the courts and commissioners, and thus becomes the possessor of a regular court document which is incontestable, and which is considered by the smuggling craft a far better and safer document than a bona fide Chinese certificate of residence.

As far as the Japanese are concerned, we are still worse off; there is no such thing as a Japanese exclusion law; by a proclamation of the President of the United States, the entry of Japanese laborers from Mexico and Canada is now prohibited if these Japanese are not in possession of passports from their government entitling them to go to the United States. When I made an investigation on the Mexican border concerning the enforcement of this order there, I found that the Japanese simply threw away their passports and crossed the border line at some convenient point, and once they were in the country it was next to impossible to get them out again, unless we could have them positively identified as having entered surreptitiously. 
The topographical conditions on these two border lines make it easy for Japanese to smuggle themselves into the country or to be smuggled in, and the absence of any registration laws such as obtain in every European country with the exception of England, and obtain particularly in Asiatic countries, is a great assistance to smuggled aliens. If we really want to keep out Chinese, Japanese, and in fact other undesirable aliens, we will have to change our laws. In the first place, we need an alien registration law, that is to say, every alien should be required to bring with him a passport from his own government, possibly with a photograph to avoid the subsequent selling or exchanging the same, it should be required that the aliens keep on their person their passport which should be stamped at the time of their arrival, and that until they become citizens of the United States, they should be required to register their residence either with the local police or with a special bureau to be created for that purpose. They should also be held to notify promptly these authorities of any change of residence, and the penalty for failure to do so should be made very severe. Americans going abroad to take up their residence in foreign countries are compelled to do the same thing, and I do not see why we could not require aliens who come to the United States for continued or temporary sojourn to do likewise. The enactment of such a law would not only keep out inadmissible Orientals, but would keep out other undesirable aliens also.

As I stated before, our immigration service is composed of excellent men, our central organization at Washington is most perfect, but our laws are inadequate, and as far as the Chinese situation is concerned, positively bad. The Chinese exclusion law ought to be taken out of the hands of the United States commissioners and United States courts. The Secretary of the Department of Commerce and Labor ought to be the sole judge of whether a Chinaman has a right to be in the United States or not, the same as he is the sole judge of the right of any other alien to be in this country. 